\title{
Effects of Organosolv Pretreatment Using Temperature-Controlled Bench-Scale Ball Milling on Enzymatic Saccharification of Miscanthus $\times$ giganteus
}

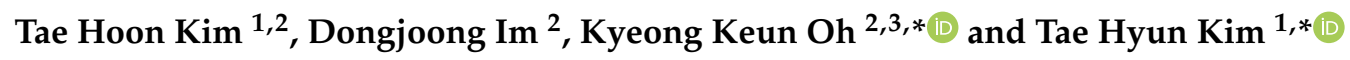 \\ 1 Department of Materials Science and Chemical Engineering, Hanyang University, Ansan, \\ Gyeonggi-do 15588, Korea; thkim@sugaren.co.kr \\ 2 R\&D Center, SugarEn Co., Ltd., Yongin, Gyeonggi-do 16890, Korea; Myred3@daum.net \\ 3 Department of Chemical Engineering, Dankook University, Yongin, Gyeonggi-do 16890, Korea \\ * Correspondence: hitaehyun@hanyang.ac.kr (T.H.K.); kkoh@dankook.ac.kr (K.K.O); \\ Tel.: +82-31-400-5222 (T.H.K.); +82-31-330-5222 (K.K.O)
}

Received: 16 August 2018; Accepted: 1 October 2018; Published: 5 October 2018

\begin{abstract}
The effect of organosolv pretreatment was investigated using a $30 \mathrm{~L}$ bench-scale ball mill reactor that was capable of simultaneously performing physical and chemical pretreatment. Various reaction conditions were tried in order to discover the optimal conditions for the minimal cellulose loss and enhanced enzymatic digestibility of Miscanthus $\times$ giganteus (MG), with conditions varying from room temperature to $170^{\circ} \mathrm{C}$ for reaction temperature, from 30 to $120 \mathrm{~min}$ of reaction time, from $30 \%$ to $60 \%$ ethanol concentration, and a liquid/solid ratio (L/S) of 10-20 under non-catalyst conditions. The pretreatment effects were evaluated by chemical compositional analysis, enzymatic digestibility test and X-ray diffraction of the treated samples. The pretreatment conditions for the highest glucan digestibility yield were determined as $170{ }^{\circ} \mathrm{C}$, reaction time of $90 \mathrm{~min}$, ethanol concentration of $40 \%$ and $\mathrm{L} / \mathrm{S}=10$. With these pretreatment conditions, the XMG (xylan + mannan + galactan) fractionation yield and delignification were $84.4 \%$ and $53.2 \%$, respectively. The glucan digestibility of treated MG after the aforementioned pretreatment conditions was $86.0 \%$ with 15 filter paper units (FPU) of cellulase (Cellic ${ }^{\circledR} \mathrm{CTec} 2$ ) per g-glucan enzyme loading.
\end{abstract}

Keywords: lignocellulosic biomass; Miscanthus; mechanical pretreatment; organosolv pretreatment

\section{Introduction}

Lignocellulosic biomass is considered to be an abundant and attractive resource in the biorefinery system. However, lignocellulosic biomass is a complex organic polymer, which is composed mainly of carbohydrate polymers (cellulose and hemicellulose) and lignin. In addition, chemical and physical barriers such as lignin and the crystalline structure of cellulose inhibit the hydrolytic reaction of enzymes on the cellulose substrate. Thus, pretreatment is an indispensable process to enhance the enzymatic saccharification of cellulose, and various pretreatment methods have been attempted extensively. Pretreatment methods can be divided into two different categories: physical and chemical pretreatment methods and biological pretreatment methods. The purpose of pretreatment is to break down the structure of the lignocellulosic biomass to improve enzymatic digestibility and thus to enable the efficient bioconversion of monomeric sugars to biochemicals [1-3].

Chemical pretreatment generally uses various catalysts such as acids, alkalis, ionic liquids, oxidizing agents, or organic solvents. Among them, acid and alkali catalysts effectively affect the biomass by either reducing the degree of polymerization or removing lignin [3,4]. Despite its many advantages, chemical pretreatment has encountered major problems such as equipment corrosion, long reaction times, high input of solvents, and sugar degradation due to the high reactivity and sever 
reaction conditions $[5,6]$. In addition, the neutralization and washing of the treated solid is essential to remove the residual chemicals; therefore, a large amount of water is required. As one type of chemical pretreatment, the organosolv pretreatment method uses a variety of organic or aqueous solvents under catalytic or non-catalytic conditions. The solvents being used in the organosolv pretreatment include ethanol, methanol, acetone, formic acid, acetic acid, and glycerol [7,8]. In addition, acid catalysts such as sulfuric acid and hydrochloric acid are generally applied to lower the $\mathrm{pH}$, because the carbohydrate-lignin complex efficiently cleaved at low $\mathrm{pH}$. The organosolv pretreatment can effectively cleave the lignin-to-lignin and lignin-to-hemicellulose bonds, which can recover high purity lignin $[8,9]$. As a result, the organosolv-pretreated biomass with low hemicellulose and lignin contents can be expected to have increased digestibility. However, organosolv pretreatment usually requires a high reaction temperature range $\left(170-210^{\circ} \mathrm{C}\right)$, long reaction time (30-120 $\left.\mathrm{min}\right)$, and high chemical loading (50-75\% in the case of ethanol and $0.5-2.0 \mathrm{wt} . \%$ of acid catalyst (such as $\mathrm{H}_{2} \mathrm{SO}_{4}$ or $\mathrm{HCl}$ )) [10-13]. However, in case of non-acid catalytic conditions (organosolv-only without additional acid), it typically requires more severe reaction condition. For example, a study of J Wildschut [14] (using a wheat straw) showed very low enzymatic digestibility of $31.7 \%$ at $170{ }^{\circ} \mathrm{C}, 60 \mathrm{~min}$, and $60 \%$ ethanol concentration. When the reaction temperature was increased by $30^{\circ} \mathrm{C}\left(200^{\circ} \mathrm{C}, 60 \mathrm{~min}, 60 \%\right.$ ethanol concentration), the digestibility was only $44.4 \%$. On the other hand, when the most severe reaction conditions $\left(210{ }^{\circ} \mathrm{C}\right.$, $90 \mathrm{~min}, 50 \%$ ethanol concentration) were applied, the enzymatic digestibility increased to $85.9 \%$.

Meanwhile, mechanical pretreatment methods commonly include grinding, milling, and comminution. They usually reduce the particle size and increase the surface area, which improves the contact surface of the biomass exposed to the enzyme [14]. Among the mechanical pretreatment methods, ball milling pretreatment severely reduces the crystallinity of cellulose by breaking hydrogen bonds in the substrate [15]. It increases the amorphous portion of cellulose, which improves the accessibility of the substrate to the enzyme [16]. In some studies on the tendency of biomass size reduction, the negative effect of milling on enzymatic digestibility was reported that the grinded MG (using hammer mill to $80 \mu \mathrm{m}$ ) resulted in only $22.5 \%$ digestibility [17]. In addition, ball mill pretreatment has previously received less attention because of its high energy consumption and long reaction time. However, integrating the mechanical and chemical pretreatment has the potential to overcome the shortcomings of chemical pretreatment method [18-20].

The main purpose of this study was to improve the pretreatment effects for Miscanthus $\times$ giganteus (MG) by combining mechanical and chemical pretreatment methods. The various reaction conditions (reaction temperature, time, and ethanol concentration) were evaluated to reduce the reaction time and decrease the reaction temperature of the organosolv pretreatment. Ethanol was used because ethanol is not only cheaper than other organic solvents, but it also has a low boiling point, which makes it easy to recover [21,22]. In general, organosolv pretreatment is supplemented with organic or inorganic acid to control the $\mathrm{pH}$ level for improved hydrolytic reaction, but this study was carried out under non-catalytic conditions to avoid the problems with an acid catalyst, such as equipment corrosion and the formation of toxic substances such as levulinic acid, 5-(hydroxymethyl)furfural (5-HMF) and furfural [1]. To the best of our knowledge, there have been few studies on the combined pretreatment with organosolv and ball milling in a large-scale reactor system. According to a study by Y. Teramoto [23] (ball milling and organosolv treatment were performed separately), enzymatic digestibility was improved to $67.4 \%$ under the pretreatment conditions of $200{ }^{\circ} \mathrm{C}, 60 \mathrm{~min}$, and $75 \%$ ethanol concentration.

In this study, one of the representative mechanical pretreatments, the ball mill pretreatment with alumina balls, was applied. A 30-L reactor was custom designed to demonstrate the combined effects of chemical and physical pretreatment. In addition, this large-scale ball mill can be operated at a maximum temperature of $200{ }^{\circ} \mathrm{C}$ and pressure of $20 \mathrm{kgf} / \mathrm{cm}^{2}$. Prior to testing the $30-\mathrm{L}$ ball mill, small lab scale tests were performed. 


\section{Results and Discussion}

\subsection{Effects of Ethanol Concentration on Compositions of Pretreated Solids and Liquids Using Small Scale Batch Reactor}

In a previous study of organosolv pretreatment, high ethanol concentration and loading were applied to achieve effective pretreatment effects; therefore, this method was expected to increase the overall processing cost. In general, the use of a lower ethanol concentration to reduce the processing cost of the organosolv pretreatment process. A preliminary experiment was conducted to determine the adequate ethanol concentration, and the chemical compositions of the organosolv-treated MG are shown in Figure 1. The reaction temperature and reaction time were fixed at $170{ }^{\circ} \mathrm{C}$ for $60 \mathrm{~min}$, which were pre-selected based on the previous studies [10-13].

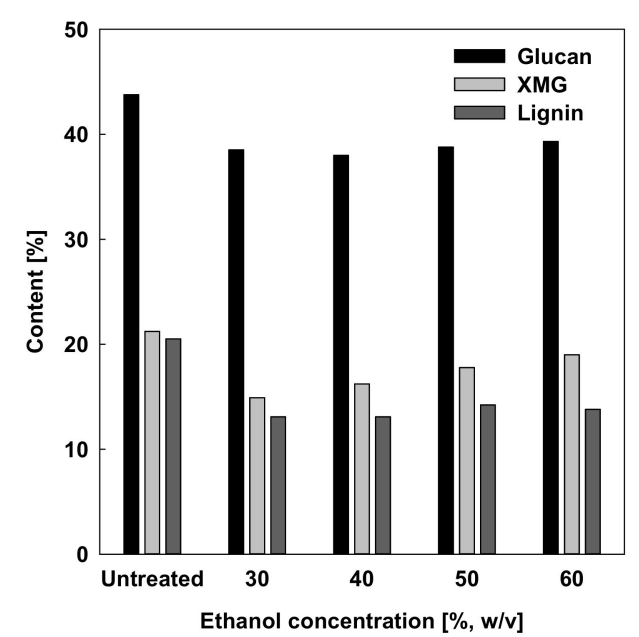

(a)

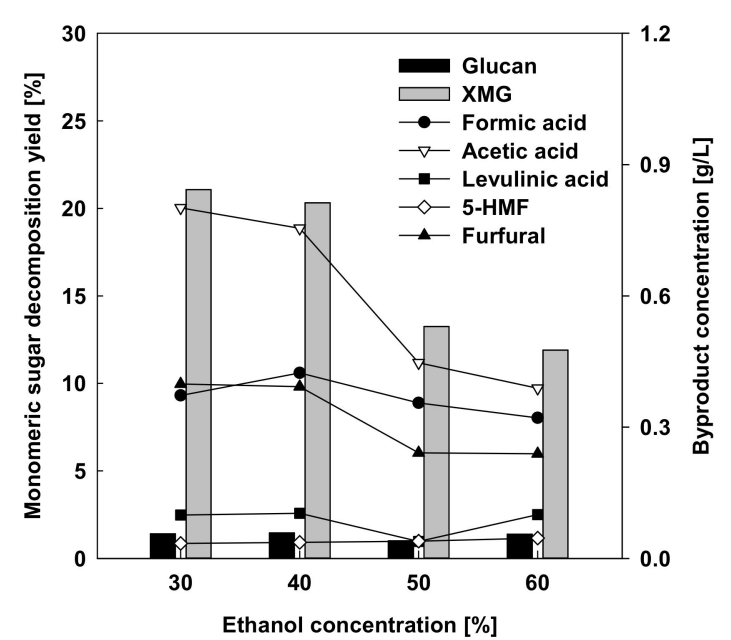

(b)

Figure 1. Effect of ethanol concentration on (a) solid content of untreated and pretreated Miscanthus $\times$ giganteus $(\mathrm{MG})$; (b) monomeric sugar and byproduct concentrations of liquid hydrolysate. Reaction conditions: $170{ }^{\circ} \mathrm{C}, 60 \mathrm{~min}$, liquid/solid $(\mathrm{L} / \mathrm{S})$ ratio $=10$. Data in the figure are based on untreated biomass (wt.\%).

As shown in Figure 1a, solubilizations of glucan (10.2-13.2\%) were generally lowers than those (10.5-29.8\%) of XMG (sum of xylan, mannan, and galactan). In addition, the glucan and XMG contents of the treated solids were more preserved as the ethanol concentration increased from $30 \%$ to $60 \%$. The reason for this phenomenon was because of the different hydrogen ion concentrations in water produced at high temperatures.

A low ethanol concentration can produce more hydronium ion $\left(\mathrm{H}_{3} \mathrm{O}^{+}\right)$than a high ethanol concentration does due to the greater water content [24]. Therefore, the $\mathrm{pH}$ value of the low ethanol concentration becomes lower than that of the high ethanol concentration, and this promotes the depolymerization of hemicellulose [25]. In contrast, lignin content showed no important change as ethanol concentrations rose from $30 \%$ to $60 \%$. The hemicellulose is bound with lignin in the cell wall of the biomass, which is more susceptible to hydrolysis under severe conditions [26,27]. Concentrated ethanol is known to be effective for lignin solubilization. However, reaction under harsh conditions is generally necessary for the effective cleavage of the lignin-hemicellulose complex, which was assumed to be related to $\mathrm{pH}$. The extent of delignification with increased ethanol concentration was shown to be consistent at the tested ethanol concentration (Figure 1a). The tendency of sugars in the residual solid upon various ethanol concentrations was similar to that of the solubilized sugar in liquid hydrolyzate shown in Figure 1b. As shown in Figure 1b, the formations of XMG and byproducts (formic acid, acetic acid, levulinic acid, 5-HMF, and furfural) in liquid hydrolyzate were decreased with increased ethanol concentration. However, the amount of glucan decomposition was 
not affected by ethanol concentration. At 30\% ethanol concentration, 21.1\% of XMG was solubilized. Under the same conditions, byproduct was formed including $0.4 \mathrm{~g} / \mathrm{L}$ of formic acid, $0.8 \mathrm{~g} / \mathrm{L}$ of acetic acid, and $0.4 \mathrm{~g} / \mathrm{L}$ of furfural (levulinic acid and 5-HMF were $<0.1 \mathrm{~g} / \mathrm{L}$ ). At $60 \%$ ethanol concentration, $11.9 \%$ of XMG was solubilized. Under these conditions, byproduct was formed and contained $0.3 \mathrm{~g} / \mathrm{L}$ of formic acid, $0.4 \mathrm{~g} / \mathrm{L}$ of acetic acid and $0.2 \mathrm{~g} / \mathrm{L}$ of furfural (c.f. levulinic acid and 5-HMF were $<0.1 \mathrm{~g} / \mathrm{L}$ ). In general, organosolv pretreatment has more advantage for delignification with high ethanol concentration. Based on these results in Figure 1b, the ethanol concentration for maximum XMG solubilization was determined to be $40 \%$, which can achieve maximum XMG solubilization and possibly more delignification.

\subsection{Organosolv Pretreatment Using Bench-Scale Ball-Milling Reactor}

\subsubsection{Effects of Reaction Temperature and Time}

The various effects of organosolv pretreatment were evaluated using a bench scale ball-milling reactor. Table 1 presents the effects of organosolv pretreatment on the chemical compositions of the treated solids and liquid hydrolyzate. As the reaction temperature increased from room temperature (RT) to $170{ }^{\circ} \mathrm{C}$, the $\mathrm{XMG}$ removal and lignin removal (delignification) were highly increased for all pretreatment times. However, the changes in XMG solubilization from the treated solids at RT and $130{ }^{\circ} \mathrm{C}$ were inconsiderable at all reaction times.

Table 1. Effects of reaction temperature and time on chemical compositions of treated solids and liquid hydrolyzate.

\begin{tabular}{|c|c|c|c|c|c|c|c|c|}
\hline \multicolumn{2}{|c|}{ Conditions } & \multicolumn{3}{|c|}{ Treated Solids } & \multicolumn{2}{|c|}{ Liquid Hydrolyzate } & \multicolumn{2}{|c|}{ Total Cons. ${ }^{1}$} \\
\hline $\begin{array}{l}\text { Temp. } \\
{\left[{ }^{\circ} \mathrm{C}\right]}\end{array}$ & $\begin{array}{l}\text { Time } \\
\text { [min] }\end{array}$ & $\begin{array}{l}\text { Glucan } \\
\text { [wt.\%] }\end{array}$ & $\begin{array}{l}\mathrm{XMG}^{2} \\
\text { [wt.\%] }\end{array}$ & $\begin{array}{c}\text { Lignin }^{3} \\
\text { [wt.\%] }\end{array}$ & $\begin{array}{l}\text { Glucan } \\
\text { [wt.\%] }\end{array}$ & $\begin{array}{c}\text { XMG } \\
\text { [wt.\%] }\end{array}$ & $\begin{array}{l}\text { Glucan } \\
\text { [wt.\%] }\end{array}$ & $\begin{array}{l}\text { XMG } \\
\text { [wt.\%] }\end{array}$ \\
\hline \multicolumn{2}{|c|}{ Untreated } & 43.8 & 21.2 & 20.5 & - & - & - & - \\
\hline \multirow{3}{*}{$\mathrm{RT}^{4}$} & 30 & 43.5 & 20.9 & 20.2 & 0.4 & 0.5 & 99.7 & 99.1 \\
\hline & 60 & 43.3 & 21.0 & 20.0 & 0.4 & 0.7 & 99.5 & 99.8 \\
\hline & 120 & 43.0 & 20.7 & 20.3 & 0.6 & 0.8 & 98.9 & 98.5 \\
\hline \multirow{3}{*}{130} & 30 & 41.7 & 20.1 & 18.3 & 0.7 & 2.1 & 96.0 & 97.0 \\
\hline & 60 & 42.3 & 20.2 & 18.5 & 0.9 & 2.6 & 97.5 & 97.7 \\
\hline & 120 & 42.7 & 20.0 & 16.7 & 0.8 & 3.4 & 98.5 & 97.7 \\
\hline \multirow{3}{*}{150} & 30 & 42.1 & 19.0 & 15.4 & 1.1 & 8.4 & 97.3 & 98.0 \\
\hline & 60 & 41.5 & 17.6 & 14.1 & 1.4 & 15.4 & 96.3 & 98.4 \\
\hline & 120 & 40.7 & 14.4 & 12.3 & 2.0 & 30.0 & 95.1 & 97.8 \\
\hline \multirow{3}{*}{170} & 30 & 41.2 & 10.1 & 10.6 & 1.9 & 40.9 & 96.0 & 88.3 \\
\hline & 60 & 40.8 & 4.2 & 10.0 & 1.9 & 65.3 & 95.0 & 85.3 \\
\hline & 120 & 35.4 & 2.0 & 7.8 & 4.1 & 74.1 & 85.0 & 83.6 \\
\hline
\end{tabular}

1 Total conservation: [(remaining (wt.\%) in treated solid + fractionated (wt.\%) in liquid)/untreated (wt.\%) in MG] $\times 100 ;{ }^{2}$ XMG: xylan + mannan + galactan; ${ }^{3}$ Lignin: acid-insoluble lignin; ${ }^{4}$ room temperature $\left(\sim 25^{\circ} \mathrm{C}\right)$. Reaction conditions: $40 \%$ ethanol concentration and $\mathrm{L} / \mathrm{S}$ ratio $=10$.

At $150{ }^{\circ} \mathrm{C}$ for $120 \mathrm{~min}, \mathrm{XMG}$ removal was $32.1 \%$, whereas the delignification was $40 \%$. On the other hand, with the $170{ }^{\circ} \mathrm{C}$ treatment, the XMG removal and delignification differed considerably between the $30 \mathrm{~min}$ and $120 \mathrm{~min}$ treatments. At $170{ }^{\circ} \mathrm{C}$ for $120 \mathrm{~min}$, the XMG removal and delignification yields were $90.6 \%$ and $62.0 \%$, respectively, which were considerably increased from the $52.4 \%$ XMG removal and $48.3 \%$ delignification of the $30 \mathrm{~min}$ treatment. The glucan contents were preserved well at all treatment conditions $(>80.8 \%)$.

The composition of liquid hydrolyzates had similar trends. As the reaction conditions became more severe, the XMG solubilization yields in the liquid hydrolyzate were proportionally increased. The solubilization yield of XMG was less than $30.0 \%$ at RT, $130{ }^{\circ} \mathrm{C}$, and $150{ }^{\circ} \mathrm{C}$, while substantial 
changes were observed at $170{ }^{\circ} \mathrm{C}$ treatment. The maximum recovery yield of $\mathrm{XMG}$ was $74.1 \%$ at $170{ }^{\circ} \mathrm{C}$ for $120 \mathrm{~min}$.

The glucan and XMG contents were decreased as the reaction temperature and time became more severe. Under the most severe conditions of $170{ }^{\circ} \mathrm{C}$ and $120 \mathrm{~min}$, total conservation of glucan and XMG were $85.0 \%$ and $83.6 \%$, respectively. This suggested that appropriate reaction conditions must be selected to accomplish the effective fractionation of sugars and lignin.

Figure 2 summarizes the byproduct formations (mainly formic acid, acetic acid, and furfural) at two different reaction temperatures $\left(150{ }^{\circ} \mathrm{C}\right.$ and $\left.170{ }^{\circ} \mathrm{C}\right)$. The byproduct formations (formic acid, acetic acid, levulinic acid, 5-HMF, and furfural) at RT and $130^{\circ} \mathrm{C}$ were not substantial, which were less than $0.3 \mathrm{~g} / \mathrm{L}$ (data not shown). Byproducts were produced by the decomposition of cellulose and hemicellulose, which typically occurred at the more severe reaction conditions [28]. Therefore, this is a good indicator to determine the severity of the reaction. At the most severe conditions (i.e., $170{ }^{\circ} \mathrm{C}$ for $120 \mathrm{~min}$ ), the productions of formic acid, acetic acid, and furfural were $1.2 \mathrm{~g} / \mathrm{L}, 3.5 \mathrm{~g} / \mathrm{L}$ and $2.0 \mathrm{~g} / \mathrm{L}$, respectively.

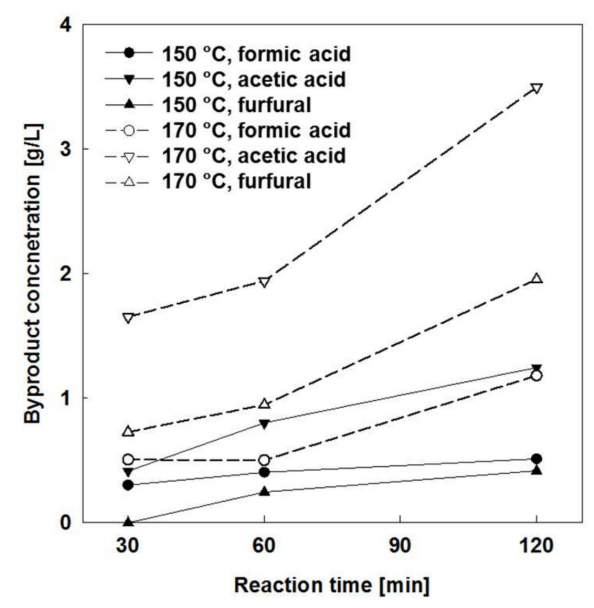

Figure 2. Effects of reaction temperature and time on concentrations of byproducts in liquid hydrolyzate. Reaction conditions: 40\% ethanol concentration and $10 \mathrm{~L} / \mathrm{S}$.

\subsubsection{Effects of Liquid/Solid (L/S) Ratio}

The effects of ethanol concentrations ( $40 \%$ and $60 \%)$, L/S ratio (10 and 20), and reaction times (from 30 to $120 \mathrm{~min}$ ) on the chemical compositions of treated solids at $170{ }^{\circ} \mathrm{C}$ are summarized in Table 2. The results indicate that the run No. 1 (ethanol concentration of $40 \%$ and L/S ratio of 10 ) conditions seem to be more severe than those of run No. 2 (ethanol concentration of $40 \%$ and L/S ratio of 20) and run No. 3 (ethanol concentration of $60 \%$ and L/S ratio of 10), because the retention of XMG in treated solid in run No. 1 was lower than those of the other runs. For the decomposition of sugar, in particular, XMG was depending on the pretreatment reaction severity, and the observed results in Table 2 were assumed to be related to the generation of acid products such as formic acid and acetic acid. Because the acetyl group of hemicellulose is cleaved as the reaction progresses, acetic acid is generated, which would drop the $\mathrm{pH}$ of the solution during the reaction and consequently increase the reaction severity, therefore promoting the hydrolysis of hemicellulose. Regardless of the amount generated, the acid concentration at an L/S of 10 is expected to be higher than that of 20. After treatment, the $\mathrm{pH}$ values of the liquid hydrolyzate of runs No. 1 and 2 at a reaction time of 120 min were 3.32 and 4.17 , respectively. This means that $\mathrm{L} / \mathrm{S}=10$ is a more severe condition than $\mathrm{L} / \mathrm{S}=20$, and this can further promote the hydrolysis of MG during the reaction. On the other hand, the high ethanol concentration (run No. 3) resulted in the formation of a low concentration of hydronium ion; therefore, the hydrolysis effect was not improved. In addition, the delignifications of runs No. 1, 2, and 3 were $58.0 \%, 61.0 \%$, and $62.0 \%$, respectively. This indicated that a $40 \%$ ethanol concentration could effectively remove the lignin $(\sim 60 \%)$. 
Table 2. Chemical compositions of solids and liquid hydrolyzates and total conservation yield of ball mill organosolv pretreatment under various reaction conditions.

\begin{tabular}{|c|c|c|c|c|c|c|c|c|c|c|}
\hline \multirow{2}{*}{ No. } & \multicolumn{3}{|c|}{ Conditions } & \multicolumn{3}{|c|}{ Treated Solid } & \multicolumn{2}{|c|}{ Liquid Hydrolyzate } & \multicolumn{2}{|c|}{ Total Conservation } \\
\hline & $\begin{array}{c}\text { EtOH } \\
{[\%]}\end{array}$ & $\begin{array}{c}\text { L/S } \\
{[-]}\end{array}$ & $\begin{array}{l}\text { Time } \\
\text { [min] }\end{array}$ & $\begin{array}{c}\text { Glucan } \\
{[\%]}\end{array}$ & $\begin{array}{c}\text { XMG } \\
{[\%]}\end{array}$ & $\underset{[\%]}{\text { Lignin }}$ & $\begin{array}{c}\text { Glucan } \\
{[\%]}\end{array}$ & $\begin{array}{c}\text { XMG } \\
{[\%]}\end{array}$ & $\begin{array}{c}\text { Glucan } \\
{[\%]}\end{array}$ & $\begin{array}{c}\text { XMG } \\
{[\%]}\end{array}$ \\
\hline \multicolumn{4}{|c|}{ Untreated } & 43.8 & 21.2 & 20.5 & - & - & - & - \\
\hline \multirow{4}{*}{1} & \multirow{4}{*}{40} & \multirow{4}{*}{10} & 30 & 41.2 & 10.1 & 10.6 & 1.9 & 40.9 & 96 & 88.3 \\
\hline & & & 60 & 40.8 & 4.2 & 10 & 1.9 & 65.3 & 95 & 85.3 \\
\hline & & & 90 & 37.5 & 3.3 & 9.6 & 1.8 & 68.6 & 87.6 & 84 \\
\hline & & & 120 & 35.4 & 2 & 7.8 & 4.1 & 74.1 & 85 & 83.6 \\
\hline \multirow{4}{*}{2} & \multirow{4}{*}{40} & \multirow{4}{*}{20} & 30 & 39.6 & 12.8 & 11.8 & 1.7 & 35.5 & 92.3 & 95.8 \\
\hline & & & 60 & 38.8 & 8.8 & 9.1 & 2.3 & 56.5 & 91 & 98 \\
\hline & & & 90 & 37.8 & 6.3 & 8.5 & 2.2 & 57.4 & 88.5 & 87.1 \\
\hline & & & 120 & 36.6 & 5.3 & 8 & 2.4 & 59.2 & 86.1 & 84.1 \\
\hline \multirow{4}{*}{3} & \multirow{4}{*}{60} & \multirow{4}{*}{10} & 30 & 42.3 & 18.3 & 12.9 & 1.8 & 9.8 & 98.5 & 95.8 \\
\hline & & & 60 & 39.5 & 15.7 & 11.5 & 1.9 & 16.8 & 92.2 & 91 \\
\hline & & & 90 & 38.8 & 13.6 & 9.4 & 2 & 24.5 & 90.6 & 88.4 \\
\hline & & & 120 & 37.5 & 8.7 & 8.6 & 2.1 & 45.3 & 87.8 & 86.3 \\
\hline
\end{tabular}

Total conservation: [(remaining (wt.\%) in treated solid + fractionated (wt.\%) in liquid)/untreated (wt.\%) in MG] $\times 100$; EtOH, ethanol; XMG: xylan + mannan + galactan; Lignin: acid-insoluble lignin. Reaction temperature: $170{ }^{\circ} \mathrm{C}$.

\subsubsection{Enzymatic Digestibility Testing of Pretreated Solids}

The enzymatic digestibility tests were performed on untreated and treated MG, and the glucan digestibilities are summarized in Figure 3. Figure 3a compares the digestibility of untreated MG and treated MG under various reaction conditions with the fixed $\mathrm{L} / \mathrm{S}$ ratio of 10 , because $\mathrm{L} / \mathrm{S}=10$ required less solvent than $\mathrm{L} / \mathrm{S}=20$ and effective hydrolysis could be expected. As shown in Figure 3a, the digestibility at three treatment temperatures, RT, $130{ }^{\circ} \mathrm{C}$ and $150{ }^{\circ} \mathrm{C}$, did not exceed $40 \%$ for $72 \mathrm{~h}$ of hydrolysis. The digestibility of the solids treated at $150{ }^{\circ} \mathrm{C}$ for 120 min was only $39.4 \%$ at $72 \mathrm{~h}$ of hydrolysis. However, the enzyme digestibility of the sample treated at $170{ }^{\circ} \mathrm{C}$ was increased to the extent to which it was similar to that using $\alpha$-cellulose. The 72-h digestibility values of the samples treated for 60 and $120 \mathrm{~min}$ were $75.7 \%$ and $96.9 \%$, respectively. In particular, the 72-h digestibility of the sample treated at $170{ }^{\circ} \mathrm{C}$ for 120 min was $8.9 \%$ higher than that $88.0 \%$ of $\alpha$-cellulose. The 72 -h digestibility values of untreated MG and $\alpha$-cellulose as the reference and control were $6.5 \%$ and $88.0 \%$, respectively.

The effects of ethanol concentration and L/S ratio on digestibility at the 90 min reaction time are presented in Figure 3b. The 72-h digestibility of treated MG with $60 \%$ ethanol was considerably lower than that of the treated solids with $40 \%$ ethanol. Although the digestibility of the two treatment conditions using $40 \%$ ethanol were close to $80 \%$ in $24 \mathrm{~h}$, the hydrolysis rate was faster than that of $\alpha$-cellulose (70.2\%) with 15 filter paper units (FPU)/g-glucan enzyme loading. Considering the aforementioned results (Table 2 and Figure 3), the following conditions were selected for the effective pretreatment and fractionation of MG: $170{ }^{\circ} \mathrm{C}$ reaction temperature, 90 min reaction time, $40 \%$ ethanol concentration and $10 \mathrm{~L} / \mathrm{S}$ ratio. The 72-h digestibility of the organosolv-treated sample (L/S of 10 with $40 \%$ ethanol concentration) was $86.0 \%$. In addition, during pretreatment reaction at $170{ }^{\circ} \mathrm{C}$ (Table 2 and Figure $3 b)$, it was observed that lignin removals were not substantial $(<58.5 \%$ of delignification) at all tested conditions. It indicated that lignin could melt or dissolve and re-precipitate back on the solids, which was to suggest that removal of lignin to the liquid phase was only a partial measure of what is happening with the lignin fraction. 


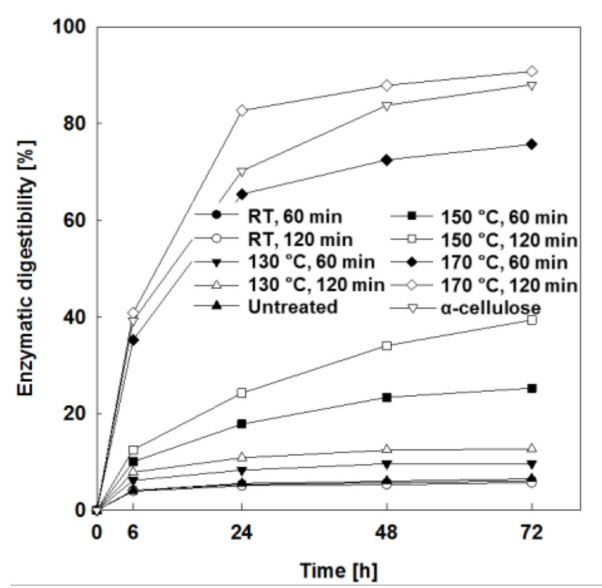

(a)

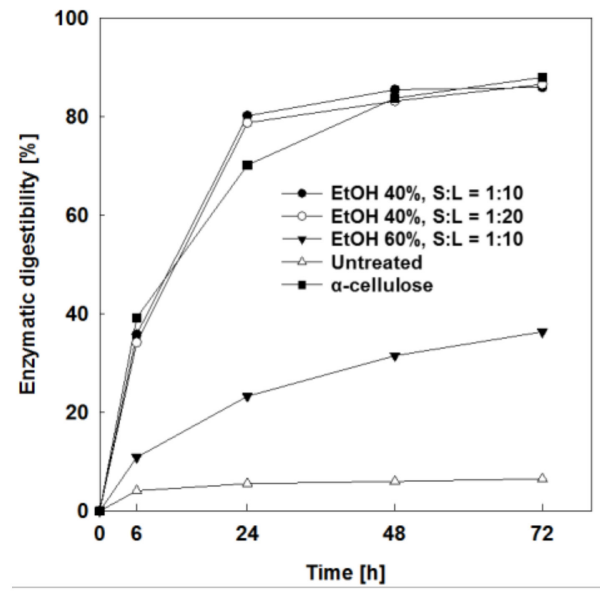

(b)

Figure 3. Enzymatic digestibility profiles of treated and untreated Miscanthus $\times$ giganteous at: (a) $40 \%$ ethanol concentration and L/S = 10 and (b) $170{ }^{\circ} \mathrm{C}$ for $90 \mathrm{~min}$. RT (room temperature); EtOH (ethanol); $\mathrm{L} / \mathrm{S}$ (liquid/solid); enzymatic hydrolysis conditions: $15 \mathrm{FPU}$ of Cellic ${ }^{\circledR} \mathrm{CTec} 2$ /g-glucan, $\mathrm{pH} 4.8,50{ }^{\circ} \mathrm{C}$, and $150 \mathrm{rpm}$.

\subsection{Crystallinity Index (CrI) of Untreated and Treated MG}

The X-ray diffraction (XRD) patterns and $\mathrm{CrI}$ of untreated and treated MG at various reaction temperatures $\left(\mathrm{RT}, 130^{\circ} \mathrm{C}, 150^{\circ} \mathrm{C}\right.$, and $170^{\circ} \mathrm{C}$ ) are presented in Figure 4 . Several studies have shown that as the reaction severity increases, the $\mathrm{CrI}$ of treated solid increases due to the removal of the amorphous parts (xylan and lignin) [29]. However, as shown in Figure 4, the crystallinities of the samples treated at RT (59.1) and $130{ }^{\circ} \mathrm{C}$ (62.9) were lower than that of the untreated sample (64.1). We speculated that the decrease in $\mathrm{CrI}$ for the samples treated at RT and $130^{\circ} \mathrm{C}$ was because of the severe size reduction effect due to the ball milling pretreatment. In contrast, for the samples treated at 150 and $170{ }^{\circ} \mathrm{C}$, the $\mathrm{CrIs}$ were 67.3 and 67.0 , respectively. As the reaction temperature increased to $>150^{\circ} \mathrm{C}, \mathrm{XMG}$ and lignin were removed and the $\mathrm{CrI}$ increased to more than that of the untreated sample, which may be due to the more removal of the amorphous portions.

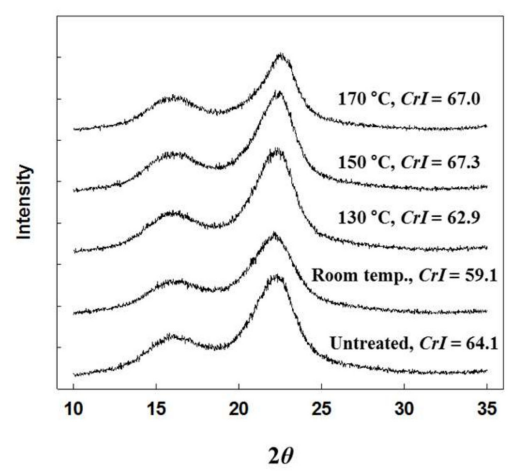

Figure 4. The diffraction patterns and CrIs (crystallinity indices) of untreated and treated Miscanthus $\times$ giganteous at different reaction temperatures. Reaction conditions: 60 min reaction time, $40 \%$ ethanol concentration and $\mathrm{L} / \mathrm{S}=10$.

\section{Materials and Methods}

\subsection{Materials}

The air-dried MG, harvested in Wanju, Jeollabuk-do, Korea in 2016, was supplied by the National Institute of Crop Science (Wanju, Jeollabuk-do, Korea). The MG was ground (Blender 7012s, Warning Commercial Inc., Stamford, CT, USA) and screened to a nominal size of 14-45 mesh 
(from 0.36 to $1.4 \mathrm{~mm}$ ). The average moisture content of the MG was determined to be $5.6 \%$ (by oven-drying at $105^{\circ} \mathrm{C}$ for $24 \mathrm{~h}$ ). The chemical composition of the untreated MG was determined using the laboratory analytical procedure (LAP) developed by the National Renewable Energy Laboratory (NREL, 2008).

The initial composition of the MG was: 43.8 wt.\% glucan, $21.2 \mathrm{wt} . \%$ XMG, $0.5 \mathrm{wt} . \%$ arabinan, $3.9 \mathrm{wt} . \%$ acetyl group, $1.0 \mathrm{wt} . \%$ acid-soluble lignin, $19.6 \mathrm{wt} . \%$ acid-insoluble lignin, $1.5 \mathrm{wt} . \%$ organosolv extractives, $5.0 \mathrm{wt} . \%$ water-soluble extractives, and $2.2 \mathrm{wt} . \%$ ash $(n=3$, standard deviations $<0.2)$. The mass closure of the untreated MG reached $98.5 \mathrm{wt} . \%$ (oven-dried biomass weight). The $\alpha$-cellulose (catalog number C8002) and ethanol (95.0\%, denatured, catalog number E0219) were purchased from Sigma-Aldrich Korea (Yongin, Gyeonggi-do, Korea) and Samchun Pure Chemical Co., Ltd. (Pyeongtaek, Gyeonggi-do, Korea), respectively.

\subsection{Experimental Setup and Operation}

\subsubsection{Small Batch Organosolv Pretreatment Reactor}

The small batch reactor (Figures 5 and A1) consisted of a control box, a reaction bath (molten salt bath and silicon oil bath), and a cooling bath (water bath). The bomb tubular reactor was made of SS-316L (internal diameter of $1.0 \mathrm{~cm}$, length of $20.0 \mathrm{~cm}$, and internal volume of $15.7 \mathrm{~cm}^{3}$ ). The temperature of the reaction bath was measured using a high temperature junction-type thermocouple (catalog number HY-72D, HANYOUNG NUX, Inchoen, Gyeonggi-do, Korea). The control box had a timer, a movement controller, and a digital temperature controller.

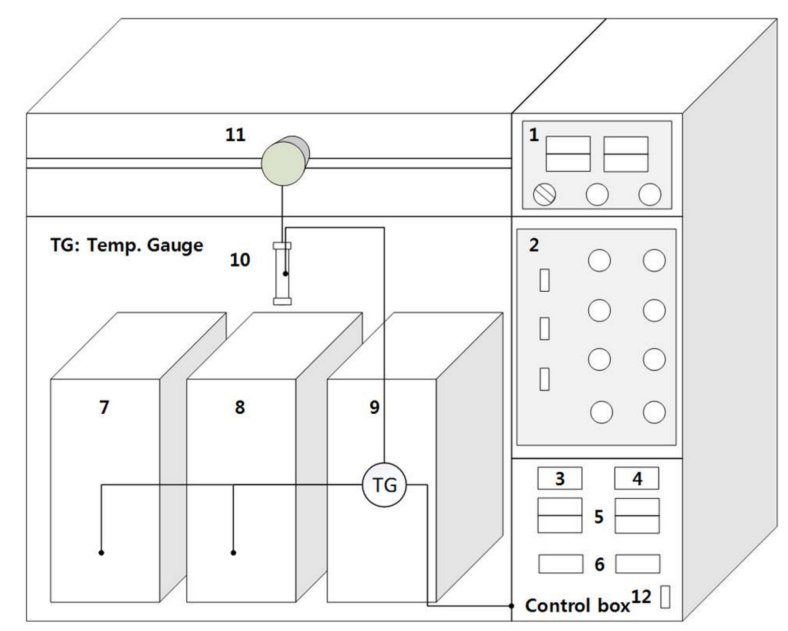

Figure 5. Schematic diagram of the small batch reactor setup: (1) timer and counter; (2) control box; (3) voltmeter; (4) ammeter; (5) thermo-controller; (6) temperature indicator; (7) salt bath; (8) silicon oil bath; (9) cooling bath; (10) batch reactor; (11) electric motor; (12) main switch.

First, $0.6 \mathrm{~g}$ (oven dry weight) MG and $6.0 \mathrm{~mL}$ ethanol $(30 \%, 40 \%, 50 \%$ or $60 \%, w / v)$ were packed into the tubular-shaped batch reactor. The reactor was placed in a molten salt bath to preheat it to the target reaction temperature $\left(170^{\circ} \mathrm{C}\right)$. To shorten the preheating time, the molten salt bath was set to $50{ }^{\circ} \mathrm{C}$ higher than the target temperature. The preheating time was less than $1 \mathrm{~min}$. When the target temperature was reached, the reactor was transferred to the silicon oil bath set at the target temperature $\left(170{ }^{\circ} \mathrm{C}\right)$ targeted time $(60 \mathrm{~min})$. At the end of the reaction time, it was transferred to a water bath and rapidly cooled. After cooling, liquid samples were removed from the reactor then then diluted 3-fold with DI (deionized) water-it facilitated the lignin precipitation. This liquid sample was subjected to the evaporation (at $55^{\circ} \mathrm{C}$ for $4 \mathrm{~h}$ ), then acid hydrolysis was carried out to analyze the liquid sample by adding $72 \%$ sulfuric acid to a final sulfuric acid concentration of $4.0 \%$. The solids removed from the reactor were washed with ethanol $(30 \%, 40 \%, 50 \%$ or $60 \%, w / v)$ and water, and were 
then dried in a $45^{\circ} \mathrm{C}$ convection oven. The dried solids were measured for weight loss and subjected to composition analysis. Each experiment was performed in triplicate.

\subsubsection{Bench Scale Ball-Milling Pretreatment Reactor}

A schematic diagram of the bench scale ball-milling reactor is shown in Figures 6 and A2. The main reactor was constructed using SS-316L (internal diameter of $30.0 \mathrm{~cm}$, depth of $42.0 \mathrm{~cm}$ and internal volume of $30 \mathrm{~L}$ ) with a wall thickness of $10.0 \mathrm{~mm}$. The pressure, temperature, and rpm could be driven up to $20 \mathrm{kgf} / \mathrm{cm}^{2}, 200{ }^{\circ} \mathrm{C}$, and $60 \mathrm{rpm}$, respectively. A metal spiral gasket was installed between the head and reactor at each of the two sides (front head and back head) to prevent pressure leakage. The front head was equipped with a hand hole $7.5 \mathrm{~cm}$ in diameter to feed in the reactant (biomass balls and ethanol) and to discharge the product. The reactor heating system was controlled of a mantle type electrical heater and capacity of heater was $10 \mathrm{~kW}$. The motor ( $380 \mathrm{~V}, 3$ Phase and $0.5 \mathrm{Hp}$ ) was installed to rotating for reactor and slip ring was installed with a rotating connector that could supply power or signals to the rotating equipment without twisting the line. The reactor was mounted on a frame with a turning roller to assist rotation and was equipped with a tilting system. The reactor was based on ball milling, but it was also designed to enable its operation under high temperature and high pressure. The alumina ball (HD, sphere type, $10 \mathrm{~mm}$ diameter and $3.6 \mathrm{~g} / \mathrm{cm}^{3}$ density) was purchased from NIKKATO Co., (Osaka, Japan). The alumina balls, MG, and ethanol $(40 \%$ or $60 \%, w / v)$ were placed in the bench scale ball milling pretreatment reactor. The ratio of ball/MG/solvent was 30:1:10 $(w / w / v)$. The reactor was preheated for $1 \mathrm{~h}$ until it reached the target temperature $\left(130{ }^{\circ} \mathrm{C}, 150{ }^{\circ} \mathrm{C}\right.$ or $170{ }^{\circ} \mathrm{C}$ ), and the reactor was rotated during preheating. The pretreatment at RT was not preheated. When the target temperature was reached, the reaction was continued for a designated time $(30,60$, 90 or $120 \mathrm{~min}$ ). At the completion of the reaction, liquid samples were removed from the reactor then subjected to the evaporation (at $55^{\circ} \mathrm{C}$ for $3 \mathrm{~h}$ ), which was then diluted 3-fold with DI-water, which facilitated the lignin precipitation. This liquid sample was subjected to the evaporation $\left(\right.$ at $55^{\circ} \mathrm{C}$ for $4 \mathrm{~h}$ ), then acid hydrolysis was carried out to analyze the sugars and lignin in the liquid sample by adding $72 \%$ sulfuric acid to a final sulfuric acid concentration of $4.0 \%$. The solids removed from the reactor were washed with ethanol $(40 \%$ or $60 \%, w / v)$ and water and separated into two portions. One portion was dried in a $45^{\circ} \mathrm{C}$ convection oven to determine weight loss (remaining solids) and subjected to composition analysis. The other portion was washed with DI-water and stored in a tightly sealed container until it underwent an enzymatic digestibility test. Each experiment was performed in duplicate.

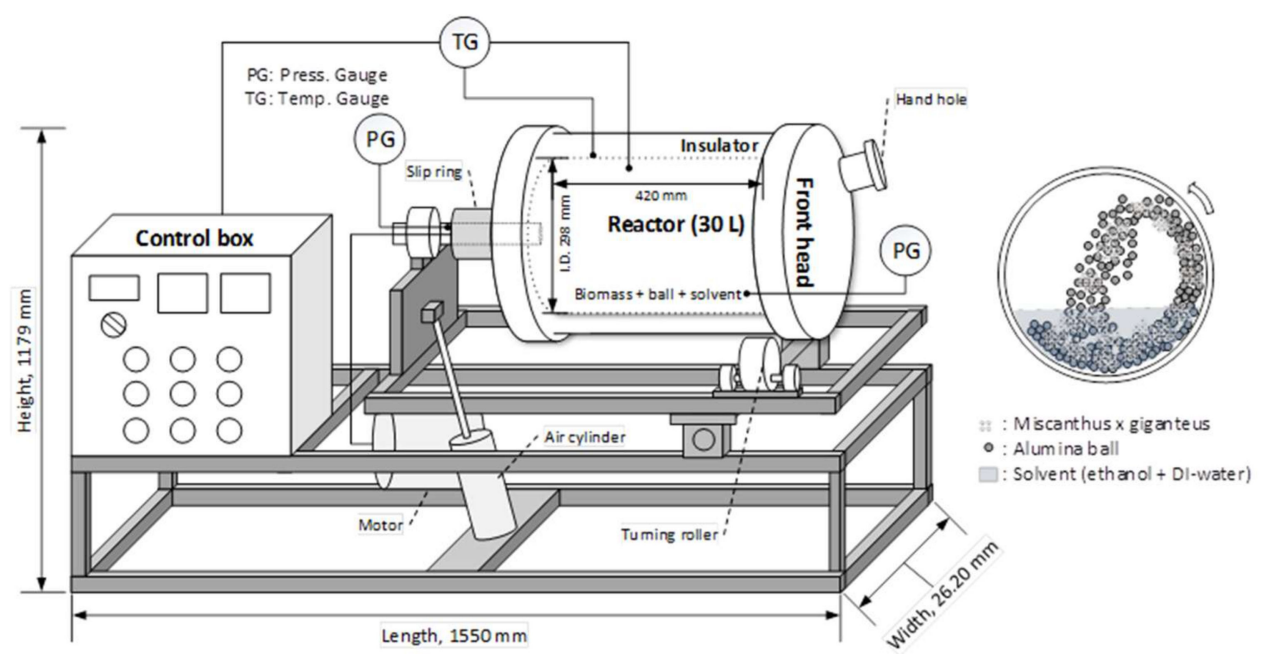

Figure 6. Schematic diagram of bench scale ball milling pretreatment reactor setup. PG (pressure gauge); TG (temperature gauge); DI (deionized) water. 


\subsection{Enzymatic Digestibility Test}

The enzymatic digestibility of untreated and treated MG was determined according to the NREL Technical Report 510-42629 [30]. The tests were performed under the following conditions: $50{ }^{\circ} \mathrm{C}$, $150 \mathrm{rpm}$, and pH 4.8 in a shaking incubator (BioFree, model BF-175SI, Co., Ltd., Dongdaemun-gu, Seoul, Korea). Enzyme loadings were $15 \mathrm{FPU} / \mathrm{g}$-glucan of commercial cellulase enzyme Cellic CTec2 (Novozymes, A/S Bagsvaerd, Denmark). The initial glucan concentration was $1.0 \%(w / v)$ based on $100 \mathrm{~mL}$ (50 mM sodium citrate buffer) of total liquid in 250-mL Erlenmeyer flasks. To prevent microbial contamination, $1.0 \mathrm{~mL}$ of $20 \mathrm{mg} / \mathrm{mL}$ sodium azide was added. Samples were taken at the appropriate sampling times $(6,12,24,48$ and $72 \mathrm{~h})$ and analyzed for glucose content using high performance liquid chromatography (HPLC) with an HPX-87H column (cat. No. 125-0098, Bio-Rad Laboratories Inc., Hercules, CA, USA). The total glucose released after $72 \mathrm{~h}$ of hydrolysis was used to calculate the enzymatic digestibility for glucan as follows:

$$
\text { Glucan digestibility }(\%)=\left[\frac{\text { Total released glucose }(\mathrm{g}) \times 0.9}{\text { Initial glucan loading }(\mathrm{g})}\right] \times 100
$$

where 0.9 is the conversion factor of glucose to the equivalent in glucan. Untreated MG and $\alpha$-cellulose were put through the same procedure as the reference and the control, respectively.

\subsection{Analytical Methods}

The extractives, chemical compositions, and liquid fractions of the solid and liquid samples were determined by following the procedures of NREL-LAP [31]. Glucose, XMG and byproducts (formic acid, acetic acid, levulinic acid, 5-HMF, and furfural) were analyzed by HPLC. The HPLC system (1260 Infinity, Agilent Technologies Inc., Santa Clara, CA, USA) was used for the measurement of monomeric sugars and byproducts. The analytical column and detector used were an Aminex HPX-87H organic acid column (Bio-Rad) and a refractive index detector (1260 RID, Agilent Technologies Inc.), respectively. The mobile phase was $5 \mathrm{mM}$ sulfuric acid in deionized water filtered through $0.2-\mu \mathrm{m}$ filters and degassed by sonication. The operating conditions for the HPLC column were $65{ }^{\circ} \mathrm{C}$ with a mobile phase with a volumetric flow rate of $0.5 \mathrm{~mL} / \mathrm{min}$. External standards consisting of glucose, XMG, arabinose, formic acid, acetic acid, levulinic acid, 5-HMF, and furfural were used for quantification.

\subsection{Crystallinity Measurement}

Crystallinities of the untreated and treated MG were determined by XRD (Rigaku Co., Tokyo, Japan) operated at $40 \mathrm{kV}$ and $40 \mathrm{~mA}$. The samples were scanned at $4^{\circ} / \mathrm{min}\left(2 \theta=10-35^{\circ}, 0.02\right.$ increment). The crystallinity indices of the samples were calculated using the following equation [32].

$$
\mathrm{CrI}=\left[\frac{I_{002}-I_{18}}{I_{002}}\right] \times 100
$$

where $I_{002}$ is the peak intensity corresponding to the 002 lattice plane of the cellulose molecule observed at $2 \theta$ equal to $22.5^{\circ}$, and $I_{18}$ (at $2 \theta=18^{\circ}$ ) is the peak intensity corresponding to amorphous cellulose.

\section{Conclusions}

In this study, we demonstrated that the combined mechanical and chemical pretreatment effectively reduced the recalcitrance of the MG. We also confirmed that the integration of mechanical and chemical pretreatment can be implemented in a large-scale reactor system. Reduced XMG, lignin, and cellulose crystallinity with minimal sugar loss could improve the enzymatic digestibility of the treated solids. For the improved enzymatic digestibility of glucan using commercial cellulase, pretreatment conditions were determined $\left(170{ }^{\circ} \mathrm{C}\right.$ reaction temperature, $90 \mathrm{~min}$ reaction time, $40 \%$ ethanol concentration, and $10 \mathrm{~L} / \mathrm{S}$ ratio). 
Author Contributions: T.H.K. as the first author conducted all experiments, summarized the data, and drafted the manuscript. D.J.I. as the co-author conducted a part of experiments and analyzed the data. T.H.K. and K.K.O. designed the reactor system as well as the overall study and experiments, interpreted the results, wrote the manuscript, and finalized the manuscript. T.H.K. and K.K.O., as the co-corresponding authors, contributed equally. All authors read and approved the final manuscript.

Funding: This work was supported by the New \& Renewable Energy Core Technology Program of the Korea Institute of Energy Technology Evaluation and Planning, and was granted financial resources from the Ministry of Trade, Industry \& Energy of the Republic of Korea (No. 20153030091050).

Conflicts of Interest: The authors declare no conflict of interest.

\section{Appendix}

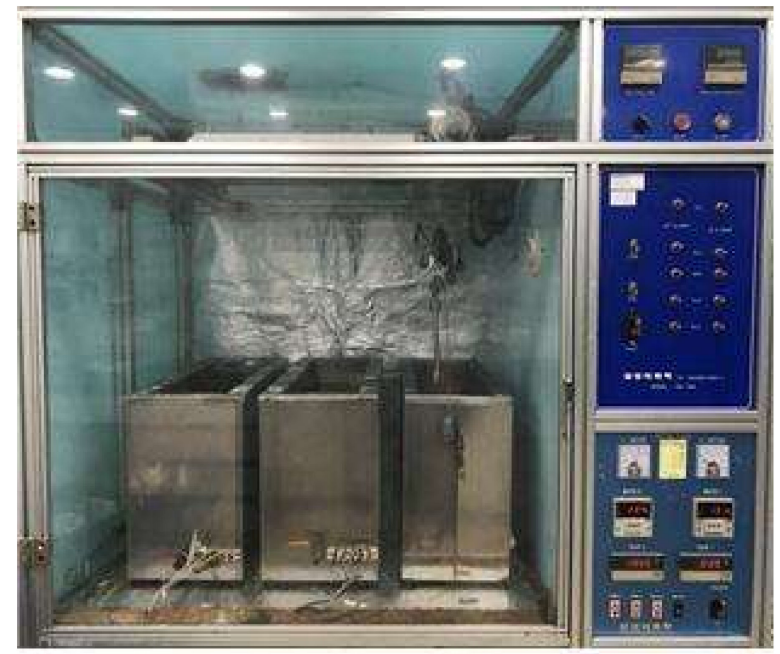

Figure A1. Small batch reactor setup for organosolv only pretreatment.

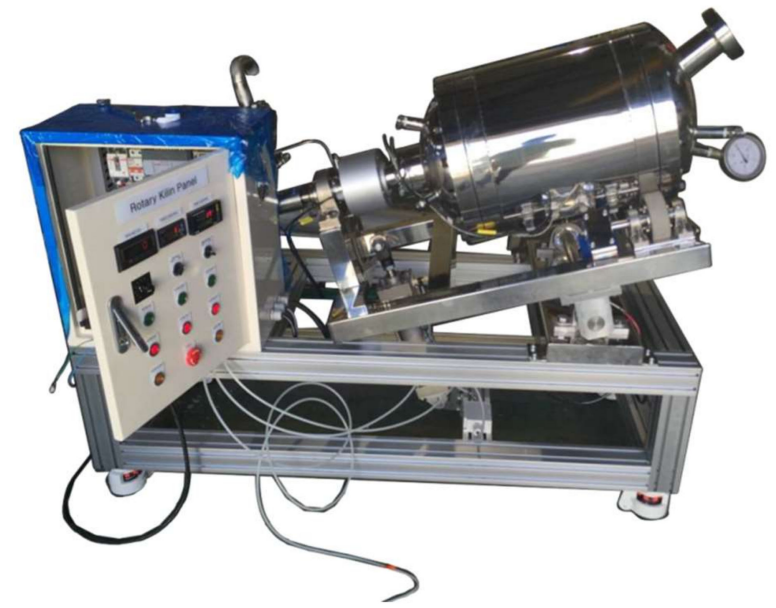

Figure A2. Bench scale ball milling pretreatment reactor setup for ball-milling organosolv pretreatment.

\section{References}

1. Chen, H.; Liu, J.; Chang, X.; Chen, D.; Xue, Y.; Liu, P.; Lin, H.; Han, S. A review on the pretreatment of lignocellulose for high-value chemicals. Fuel Process. Technol. 2017, 160, 196-206. [CrossRef]

2. Kim, T.H.; Kim, T.H. Overview of technical barriers and implementation of cellulosic ethanol in the US. Energy 2014, 66, 13-19. [CrossRef]

3. Zabed, H.; Sahu, J.N.; Boyce, A.N.; Faruq, G. Fuel ethanol production from lignocellulosic biomass: An overview on feedstocks and technological approaches. Renew. Sustain. Energy Rev. 2016, 66, 751-774. [CrossRef] 
4. Szczodrak, J.; Fiedurek, J. Technology for conversion of lignocellulosic biomass to ethanol. Biomass Bioenergy 1996, 10, 367-375. [CrossRef]

5. Rao, L.V.; Goli, J.K.; Gentela, J.; Koti, S. Bioconversion of lignocellulosic biomass to xylitol: An overview. Bioresour. Technol. 2016, 213, 299-310.

6. Hassan, S.S.; Williams, G.A.; Jaiswal, A.K. Emerging Technologies for the Pretreatment of Lignocellulosic Biomass. Bioresour. Technol. 2018, 262, 310-318. [CrossRef] [PubMed]

7. Salapa, I.; Katsimpouras, C.; Topakas, E.; Sidiras, D. Organosolv pretreatment of wheat straw for efficient ethanol production using various solvents. Biomass Bioenergy 2017, 100, 10-16. [CrossRef]

8. Zhang, K.; Pei, Z.; Wang, D. Organic solvent pretreatment of lignocellulosic biomass for biofuels and biochemicals: A review. Bioresour. Technol. 2016, 199, 21-33. [CrossRef] [PubMed]

9. Pan, X.; Kadla, J.F.; Ehara, K.; Gilkes, N.; Saddler, J.N. Organosolv ethanol lignin from hybrid poplar as a radical scavenger: Relationship between lignin structure, extraction conditions, and antioxidant activity. J. Agric. Food Chem. 2006, 54, 5806-5813. [CrossRef] [PubMed]

10. Wildschut, J.; Smit, A.T.; Reith, J.H.; Huijgen, W.J. Ethanol-based organosolv fractionation of wheat straw for the production of lignin and enzymatically digestible cellulose. Bioresour. Technol. 2013, 135, 58-66. [CrossRef] [PubMed]

11. Pan, X.; Gilkes, N.; Kadla, J.; Pye, K.; Saka, S.; Gregg, D.; Ehara, K.; Xie, D.; Lam, D.; Saddler, J. Bioconversion of hybrid poplar to ethanol and co-products using an organosolv fractionation process: Optimization of process yields. Biotechnol. Bioeng. 2006, 94, 851-861. [CrossRef] [PubMed]

12. Geng, A.; Xin, F.; Ip, J.Y. Ethanol production from horticultural waste treated by a modified organosolv method. Bioresour. Technol. 2012, 104, 715-721. [CrossRef] [PubMed]

13. Sun, Y.C.; Wen, J.L.; Xu, F.; Sun, R.C. Structural and thermal characterization of hemicelluloses isolated by organic solvents and alkaline solutions from Tamarix austromongolica. Bioresour. Technol. 2011, 102, 5947-5951. [CrossRef] [PubMed]

14. Lee, J.H.; Kwon, J.H.; Kim, T.H.; Choi, W.I. Impact of planetary ball mills on corn stover characteristics and enzymatic digestibility depending on grinding ball properties. Bioresour. Technol. 2017, 241, 1094-1100. [CrossRef] [PubMed]

15. Avolio, R.; Bonadies, I.; Capitani, D.; Errico, M.E.; Gentile, G.; Avella, M. A multitechnique approach to assess the effect of ball milling on cellulose. Carbohydr. Polym. 2012, 87, 265-273. [CrossRef]

16. Zhao, H.; Kwak, J.H.; Wang, Y.; Franz, J.A.; White, J.M.; Holladay, J.E. Effects of crystallinity on dilute acid hydrolysis of cellulose by cellulose ball-milling study. Energy Fuels 2006, 20, 807-811. [CrossRef]

17. Khullar, E.; Dien, B.S.; Rausch, K.D.; Tumbleson, M.E.; Singh, V. Effect of particle size on enzymatic hydrolysis of pretreated Miscanthus. Ind. Crops Prod. 2013, 135, 11-17. [CrossRef]

18. Liu, H.; Pang, B.; Zhao, Y.; Lu, J.; Han, Y.; Wang, H. Comparative study of two different alkali-mechanical pretreatments of corn stover for bioethanol production. Fuel 2018, 221, 21-27. [CrossRef]

19. Shi, Z.; Liu, Y.; Xu, H.; Yang, Q.; Xiong, C.; Kuga, S.; Matsumoto, Y. Facile dissolution of wood pulp in aqueous $\mathrm{NaOH} /$ urea solution by ball milling pretreatment. Ind. Crops Prod. 2018, 118, 48-52. [CrossRef]

20. Dai, L.; Li, C.; Zhang, J.; Cheng, F. Preparation and characterization of starch nanocrystals combining ball milling with acid hydrolysis. Carbohydr. Polym. 2018, 180, 122-127. [CrossRef] [PubMed]

21. Zhao, X.; Cheng, K.; Liu, D. Organosolv pretreatment of lignocellulosic biomass for enzymatic hydrolysis. Appl. Microbiol. Biotechnol. 2009, 82, 815. [CrossRef] [PubMed]

22. Nitsos, C.; Rova, U.; Christakopoulos, P. Organosolv fractionation of softwood biomass for biofuel and biorefinery applications. Energies 2017, 11, 50. [CrossRef]

23. Teramoto, Y.; Tanaka, N.; Lee, S.H.; Endo, T. Pretreatment of eucalyptus wood chips for enzymatic saccharification using combined sulfuric acid-free ethanol cooking and ball milling. Biotechnol. Bioeng. 2008, 99, 75-85. [CrossRef] [PubMed]

24. Yan, J.; Joshee, N.; Liu, S. Utilization of hardwood in biorefinery: A kinetic interpretation of pilot-scale hot-water pretreatment of Paulownia elongata woodchips. J. Biobased Mater. Bioenergy 2016, 10, 339-348. [CrossRef]

25. Liu, S. Woody biomass: Niche position as a source of sustainable renewable chemicals and energy and kinetics of hot-water extraction/hydrolysis. Biotechnol. Adv. 2010, 28, 563-582. [CrossRef] [PubMed] 
26. Yuan, T.Q.; You, T.T.; Wang, W.; Xu, F.; Sun, R.C. Synergistic benefits of ionic liquid and alkaline pretreatments of poplar wood. Part 2: Characterization of lignin and hemicelluloses. Bioresour. Technol. 2013, 136, 345-350. [CrossRef] [PubMed]

27. Weinwurm, F.; Turk, T.; Denner, J.; Whitmore, K.; Friedl, A. Combined liquid hot water and ethanol organosolv treatment of wheat straw for extraction and reaction modeling. J. Clean. Prod. 2017, 165, 1473-1484. [CrossRef]

28. Kim, T.H.; Jeon, Y.J.; Oh, K.K.; Kim, T.H. Production of furfural and cellulose from barley straw using acidified zinc chloride. Korean J. Chem. Eng. 2013, 30, 1339-1346. [CrossRef]

29. Kim, J.S.; Lee, Y.Y.; Kim, T.H. A review on alkaline pretreatment technology for bioconversion of lignocellulosic biomass. Bioresour. Technol. 2016, 199, 42-48. [CrossRef] [PubMed]

30. Selig, M.; Weiss, N.; Ji, Y. Enzymatic Saccharification of Lignocellulosic Biomass; NREL/TP-510-42629; National Renewable Energy Laboratory: Golden, CO, USA, 2018.

31. Sluiter, A.; Hames, B.; Ruiz, R.; Scarlata, C.; Sluiter, J.; Tmpleton, D.; Crocker, D. Determination of Structural Carbohydrates and Lignin in Biomass; NREL/TP-510-42618; National Renewable Energy Laboratory: Golden, CO, USA, 2012.

32. Cao, Y.; Tan, H. Study on crystal structures of enzyme-hydrolyzed cellulosic materials by X-ray diffraction. Enzyme Microb. Technol. 2005, 36, 314-317. [CrossRef]

(C) 2018 by the authors. Licensee MDPI, Basel, Switzerland. This article is an open access article distributed under the terms and conditions of the Creative Commons Attribution (CC BY) license (http:/ / creativecommons.org/licenses/by/4.0/). 